\title{
Developing Worksheets for Fine Art Materials by Using Discovery Learning Model Based on the Scientific Approach
}

\author{
Wisdiarman, Abd. Hafiz, Suib Awrus, and Zubaidah \\ Fine Art Education Study Program, Faculty of Languages and Arts, \\ Universitas Negeri Padang \\ wisdiarman@gmail.com
}

\begin{abstract}
Worksheets, one of the instructional media, have to be prepared before teaching since they affect the teaching and learning process. The 2013 curriculum requires the learning implementation to be applied based on the scientific approach including the development of worksheets. However, it has not yet been applied at schools. This research aimed at finding out and developing worksheets based on the scientific approach using discovery learning model suitable, practical and effective to improve students abilities. The design of the research was research and development using the 4-D model: define, design, develop, and disseminate (Thiagarajan and Sivasailam, in Trianto, 2009). The quality of the worksheets was analyzed from several points. Its suitability was analyzed from experts points of view while its practicality was analyzed from teacher's and students' responses. In addition, the effectiveness of the worksheets was analyzed from students learning outcomes. The instruments of the research were expert validation sheets, students and teachers response questionnaires, and test. The research result shows that the worksheets development have fulfilled the valid category. It was analyzed from the presentation, content, language and graphics found in the worksheets. It means the worksheets based on the scientific approach using the discovery learning model are suitable.
\end{abstract}

Keywords - Worksheets, Scientific Approach, Discovery Learning Model, Fine Art Materials

\section{INTRODUCTION}

Art subject is included in the group of aesthetic subject which is aimed to increase the ability of sensitivity, expression, and appreciation of beauty and harmony. The learning of art and culture has multilingual, multidimensional, and multicultural characteristics. Multilingual characteristics means the process of developing self expression creatively in various ways and media such as language, sounds, motion, roles, and in various blends. Multidimensional characteristic means the process of developing the various competencies including conception (knowledge, comprehending, analyzing, and evaluating), appreciation, and creation by integrating harmoniously the element of the aesthetic, partial visual, logical, kinesthetic, and ethical. Multicultural characteristic means the appreciation toward the awareness development and the ability to appreciate toward the various cultures in Indonesian archipelago and outside. This is means as a form of democratic that enables someone live in a good manner and tolerant in a pluralistic society and culture (The attachment of Regulation of the Minister of National Education No 22, 2006). Therefore, this learning must be brought to schools, such as SD / MI, SMP / MTsN and SMA / SMK / MAN. However, the implementation in schools, especially in junior high school is still not in line with the expectation.

In order to make the learning works well, teachers have to prepare the set of good learning tools too. Learning tool is a set of media or facilities used by the teachers and the students in the process of learning in the classroom (Anonymous, 2008). Many media must be prepared before teaching and there is a media that gives good significant influence in the learning process, namely worksheets. Worksheet is aset of sheets for students in learning activities to facilitate the understanding of the subject matter obtained (Arsyad, 2011). This worksheet contains the tasks that must be done by the students (Majid, 2014). In addition, worksheet also contains brief materials and instructions on the implementation of tasks that must be completed by students. The materials have to refer to the basic competencies which have to be achieved (Prastowo, 2014).

Based on the observations conducted in Junior High School Bukittinggi, it was seen that the worksheet used by the teachers was more to evaluate student learning outcomes given at the end of learning or as homework materials. In addition, the worksheets had less varied types of questions, the students were often asked to fill in the blanks or answer the multiple choice questions. So, those sheets did not contain the activities in which the students learn something directly in discovering or applying concept. In fact, worksheet is not just a teacher' tool in learning or just complementary explanation of a concept, but worksheet should be as a trigger to discover that concept itself.

Based on the results of interviews with some teachers from the grade seven Junior High School Bukittinggi, it is found that students' understanding of art material is very low, both theory and practice. This was indicated by the number of students who have not completed in every task given, and this impacted on the low student learning outcomes. 
The solution that can be used to overcome the problems above is by using the worksheet based on scientific approach by using the model of discovery learning. Kurniasih and Sani (2014) argued that learning with a scientific approach is a learning process designed in such a way that learners actively construct a concept, laws, or principle through the stages namely, observing (to identify or find problems), formulating problems, propose or formulate hypotheses, collecting data with various techniques, analyzing data, drawing conclusions and communicating a "found" concept, law or principle. The main point is that the scientific approach prefers more in students' creativity and findings (Kosasih, 2014). Besides, the discovery learning is the learning model that emphasizes learning through discovery (discovery learning). Romiszowski in Wisdiarman (2007) calls learning through discovering as the learning through experiencing. The point is that students master the learning material, not because of their teachers, but because of finding through the process of experiencing or through the various activities.

The scientific approach is used in 2013 curriculum. One of the models that can be used in the implementation of the 2013 curriculum is the discovery learning model, with the stimulation steps, problem identification, data collection, and verification and drawing conclusions (Kemendikbud, 2013). So, the teachers should use this learning model in their class, including in preparing learning tools especially worksheet. Several studies had been conducted related to this approach. Some studies are conducted by Arik Diyah Muryani (2015) and Ratulani Juwita (2015). In their studies, they concluded that worksheet which is based on scientific approach or discovery learning model proved effective in improving students' learning outcomes.

Based on the observation and information which are got from the head of SMP and Chairman of MGMP of SMP in the field of culture in Bukittinggi, the worksheet based on scientific approach by using the model of discovery learning for the subject of art and cultural, the material is not available yet in junior high school of Bukittinggi. For art material, the teachers still use the existing worksheet in textbooks.

Based on the explanation above, the development of worksheet based on scientific approach by using the discovery learning model in the subject of art and culture in the seventh grade of junior high school Bukittinggi is needed. For that purpose, research is done to develop worksheet as supporting learning in accordance with curriculum 2013 that is worksheet based on scientific approach with discovery learning model. The formulation of the research is how to develop worksheet based on scientific approach by using discovery learning model which is valid, practical, and effective on the subject of art for grade VII of students in Bukittinggi. This research aims to develop worksheet based on scientific approach by using discovery learning model which is valid, practical and effective on the subject of art for grade VII students in Bukittinggi.

\section{METHOD}

The type of this research was Research and Development (R \& D) which refers to the model of development of 4-D model, namely define, design, development, and disseminate (Thiagarajan, Sivasailam , in Trianto, 2009). However, this research was only done until the development stage (develop). The define stage was done in the four steps of activity, those were; 1) analyzing the needs of teachers and students to find out the problems in learning related to the roles of worksheet, 2) analyzing the curriculum, 3) analyzing the subject materials, and 4) analyzing the students' characteristics. The design stage was done by arranging worksheet based on scientific approach by using discovery learning model for art ubject in the material of fine art in grade VII SMP. The worksheet design takes into account the feasibility aspects of the approach, content, presentation, language, and graphicic. At this stage of design, the framework of worksheet is organized based on the components of worksheet. In the development stage, the worksheet was tested to see the validity of the worksheet and the product testing was also done. The validity test aimed to see the feasibility of approach, content, presentation, language, and graphic of worksheet designed. The product testing aimed to know; 1) the level of practicality of the worksheet which has been developed, that is to know how benefits, ease of use, and efficient in terms of time by using the worksheet and 2) the level of effectiveness of the worksheet, that is to know whether the worksheet developed is effective to improve student learning outcomes or not. The development which is conducted in the first year is up to the test of validity of the worksheet and limited or small scale product trial to know the level of practicality, readability, usage and so on. While for large-scale product trial was done to know the effectiveness of the worksheet products which had done in the second year.

The research procedures performed in the first year is only up to the stage of development, especially in the stage of validity testing. It means that the worksheet produced is the valid worksheet which is based on scientific approach by using discovery learning model according to experts. While, the dissemination stage (disseminate) was done in the second year. The instruments used in this research are interview guides and questionnaires and sheets for validity, questionnaire for teachers' and students' response, and test. The questionnaires are the questionnaire to see the validity, questionnaire to see the practicality, and the test to see the effectiveness. The technique of data analysis which is used in this research was the descriptive data analysis technique. The technique was done to get the worksheet which was worthy and qualified in usage and meets the valid criteria or feasible from aspects of approach, content/material, presentation, language and graphic. The data validity was obtained from the assessment done by the experts by using the worksheet scoring/validity sheets. The data were analyzed quantitatively and qualitatively. From this likert scale, the data was analyzed by the formula below:

$$
\text { Percentage }=\frac{\text { Scores obtained }}{\text { Scores maximal }} \text { X } 100 \%
$$


Based on the percentage, then it was interpreted by using the Ridwan Criteria in the Table 1 below:

Table 1 The Interpretation of Feasibility

\begin{tabular}{|l|l|}
\hline Percentage & Criteria \\
\hline $81 \%-100 \%$ & Very Feasible \\
\hline $61 \%-80 \%$ & Feasible \\
\hline $41 \%-60 \%$ & Average \\
\hline $21 \%-40 \%$ & Not Feasible \\
\hline $0 \%-20 \%$ & Poor \\
\hline
\end{tabular}

(Source: Ridwan, 2013)

A. Finding

\section{FINDING AND DISCUSSION}

The worksheet produced in this research is the worksheet based on scientific approach by using the discovery learning model on the subject of art in fine art material in class VII SMPN 2 Bukitinggi. This worksheet is designed in line with the steps of learning based on scientific approach with the model of discovery learning. There are five steps discovery learning model based on scientific approach, namely; 1) giving stimulus, 2) formulating problems, 3) collecting data, 4) processing data, 5) proofing and 6) drawing conclusions.

In order to make the learning tools in fine arts materials are appropriate with the worksheet based on scientific approach by using the discovery learning model, it should be validated by the experts to meet the perfect one. The worksheet based on scientific approach by discovery learning model on the subject of art of the fine art material has been done in validity test to see the feasibility of approach, content/ material, presentation, language, and graphic. The results of the validity all aspects can be seen in the following table:

Table 2: The Result of Validity as a Whole

\begin{tabular}{|l|l|l|l|}
\hline No. & \multicolumn{1}{|c|}{ Aspect } & \multicolumn{1}{|c|}{ Score } & \multicolumn{1}{c|}{ Category } \\
\hline 1 & Approach & $88,57 \%$ & Very Valid \\
\hline 2 & Content & $86,67 \%$ & Very Valid \\
\hline 3 & Presentation & $92 \%$ & Very Valid \\
\hline 4 & Language & $88 \%$ & Very Valid \\
\hline 5 & Graphic & $92 \%$ & Very Valid \\
\hline & Average & $\mathbf{8 9 , 4 5 \%}$ & Very Valid \\
\hline
\end{tabular}

Based on the above table, it is showed that the average of validation of the worksheet as a whole from experts is $89.45 \%$. If it is calculated using the criteria, then the results obtained are categorized very valid. Thus it can be said that from the aspect of approach, content, presentation, language, and graphic, worksheet which is based on scientific approach with discovery learning model on the subject of art of fine art material in class VII SMP is categorized very valid.

To strengthen the validity results of the experts above, the researchers conducted a limited trial or small scale in school as a user of the worksheet, to know the practicality, the level of readability of the worksheet, ease of usage and so forth. In this experiment, the samples for validation in school are two art teachers and six students in grade VII.2 SMPN 2 Bukittinggi. The results of teachers' and students' response toward the worksheet developed can be seen from the table below:

Table 3: The Result of a Limited Trial of the Product

\begin{tabular}{|c|l|l|l|}
\hline No. & \multicolumn{1}{|c|}{ Aspect } & Score/Percentage & \multicolumn{1}{c|}{ Category } \\
\hline 1 & Teachers' Response & $88,67 \%$ & Very Valid \\
\hline 2 & Students' Response & $87,5 \%$ & Very Valid \\
\hline & Average & $\mathbf{8 8 , 0 8 \%}$ & Very Valid \\
\hline
\end{tabular}

Based on the findings above, both the validation results of experts and the results of limited testing, it can be concluded that the worksheet based on scientific approach by using discovery learning model that has been developed by researchers is very valid and feasible to be used in the process of learning art in class VII SMP.

\section{B. Discussion}

Based on the results of testing that had been done, it is noticed that the worksheet which is designed based on scientific approach by using discovery learning model can be categorized into feasible/valid to be used in class VII SMPN Bukittinggi. The 
validation of the product includes five aspects namely, approach, content, presentation, language, and graphic.The aspects of approach used; the approach used in developing worksheet is a scientific approach by using discovery learning model. The result of worksheet validation from the aspect of approach used in worksheet get the percentage $88,57 \%$. It means that worksheet of the subject of art and cultural which is based on the scientific approach by using discovery learning model is categorized very valid. This is because all activities in the worksheet have followed the steps of scientific approach by using discovery learning model. These steps start from observing, questioning, gathering information, associating and communicating. These steps are integrated into the discovery learning model, namely; 1) giving stimulus, 2) identifying problem, 3) collecting data, 4) proofing and 5) drawing conclusions/generalization.

The aspects of content; the percentage of validation related to the aspect of content in the worksheet is located in $86.67 \%$. It means that the worksheet of art subject based on a scientific approach by using discovery learning model is categorized very valid from the aspect of content/material. This is because the problems and exercises in the worksheet have been prepared in line with the Basic Competency and is sufficient to achieve the indicators of the competence achievement. Besides, worksheet is also designed in line with the students' cognitive development, the needs of teaching materials, and the material substance, and is presented systematically and logically and correctly based on the knowledge of fine art.

The aspect of presentation; the percentage of validation related to the presentation aspect in the worksheet is located in $92 \%$. This aspect is also categorized as very valid, because the worksheet has a clear objective activities, complete structures (title, learning instruction/student's instruction, competence to be achieved, supporting information, tasks, work steps and assessment), systematic, the sequence of the lesson is appropriate with the level of student's ability and complete information.

The aspects of language; the percentage of validation related to the presentation aspect in the worksheet is located in $92 \%$. This aspect is also categorized as very valid, because the worksheet is designed by using good and correct language in line with the principle of Indonesian language. The worksheet also uses a clear language, simple and communicative and it is appropriate with the level of students' ability in junior high school, so the presentation of the material on the worksheet can be understood by the students well and finally able to direct students to do the tasks and get the expected answers.

The aspect of graphic; the percentage of validation related to the graphic aspect in the worksheet is located in $92 \%$. This aspect is also categorized very valid, because worksheet is designed by using good types and size of letters and the interesting layouts. The worksheet is also equipped with the good illustrations/pictures/ photos and those are related to the concept. Furthermore, the cover is also designed with the interseting look and it represents the contents. With this presentation, the students are motivated and interested in doing the tasks and exercises that are in the worksheet. This is in accordance with the opinion of Putri and Mitarlis (2015) who states that the worksheet can attract and motivate students because the presentation uses good writing, color, and image in accordance with the presented materials so that it helps the students understand the material and make them interested to open it.

After tested by the experts related to the validity, the researchers conducted a limited trial or small scale of users in the school. Those users are teachers and students. The percentage of average of limited test results or small scales is in $88.08 \%$. or categorized as very valid. This can be seen from the teachers' and students' response to the worksheet. From both teachers' and students' response, it is noticed that the worksheet which I developed is feasible in terms of the guidance used, the language used, the time taken, the presentation, the material, and the activities presented in it.

\section{CONCLUSION AND RECOMMENDATION}

\section{A. Conclusion}

This research and development aimed to develop the worksheet based on scientific approach by using discovery learning model on art subject of fine art in class VII SMP. Based on the finding of the research, it can be concluded that worksheet based on scientific approach by using discovery learning model on art subject in class VII SMP is valid in terms of approach, content, presentation, language, and graphic".

\section{B. Suggestion}

Based on the research that has been done and the conclusion that has been described above, there are some recommendation. Those are 1) worksheet based on scientific approach by using discovery learning model on art subject of fine art in class VII SMP can be used as a model for teachers to develop worksheet on other subjects, 2) for the teachers especially art and culture teachers, it is hoped that they are able to develop the learning tools especially worksheet -based scientific approach by using discovery learning model on other materials, such as music art, dance art, and theater art.

\section{References}

Arsyad, Azhar. (2011). Media Pembelajaran. Jakarta: PT. Rajagrafindo Persada.

Hafiz, Abd, dan Wisdiarman. (2012). Discovery learning Sebagai Model Strategi Pembelajaran Seni Rupa. Jurnal Seni dan Desain Ranah Seni. Volume 05, No.02, Maret 2012, hal.949-954

Kementerian Pendidikan dan Kebidayaan RI. (2013). Seni Budaya SMP Kelas VII. Buku Guru. Jakarta: Kementerian Pendidikan dan Kebidayaan 
(2013). Model Pembelajaran Penemuan (discovery Learning) Jakarta: Kementerian Pendidikan dan Kebudayaan (2013). Peraturan Menteri Pendidikan dan Kebudayaan RI No.65 Tahun 2013 Tentang Standar Proses Pendidikan Dasar dan Menengah

Kosasih. (2014). Strategi Belajar dan Pembelajaran Implmentasi Kurikulum 2013. Bandung: Yrama Widya

Kurniasih, Imas dan Sani, Berlin. (2014). Sukses Mengimplementasikan Kurikulum 2013. Jakarta: Kata Pena

Majid, Abdul dan Rochman Chaerul. (2014). Pendekatan Saintifik Dalam Implementasi Kurikulum 2013. Bandung: PT Remaja Rosdakarya

Muryani, Arik Diyah dan Rochmawati. (2015). "Perbedaan Hasil Belajar Siswa Menggunakan Model Pembelajaran Discovery Learning yang Berbantuan dan Tanpa Berbantuan Lembar Kerja Siswa”. Jurnal Pendidikan Ekonomi (Online) Vol. 1 (1): Hal. 1-6.

Prastowo, Andi. (2014). Panduan Kreatif Membuat Bahan Ajar Inovatif. Jogjakarta: DIVA Press

Putri, D. dan Mitarlis. (2015). Pengembangan Lembar Kerja Siswa Berbasis Mind Mapping pada Materi Laju Reaksi 6untuk Melatih Keterampilan Berpikir Siswa Kelas XI SMA. UNESA Journal of Chemical Education 4(2) 340-348.

Riduwan. (2013). Skala Pengukuran Variabel-Variabel Penelitian. Bandung: Alfabeta

Trianto. (2009). Mendesain Model Pembelajaran Inovatif Progresif. Jakarta: Kencana.

Wisdiarman (2007) Pengaruh Strategi Pembelajaran Discovery dan Motivasi Belajar Terhadap Hasil Belajar Menggambar Bentuk. Jurnal Forum Pendidikan, 3(2): 111-118

Wisdiarman dan Zubaidah. (2014). Pembelajaran Berbasis Kurikulum 2013. Padang: Seni Rupa FBS UNP Padang 